\title{
Snake and Ladder Games in Cognition Development on Students with Learning Difficulties
}

\author{
K. Srinivasan \\ Department of Pedodontics and Preventive Dentistry, CKS Teja Institute of Dental Science and Research, Tirupati, Andhra Pradesh, \\ India
}

Email for correspondence: skskskpedo@gmail.com

\begin{abstract}
Introduction: School students play an important role in oral health care and promotion. Learning in these institutions becomes ineffective unless it leads to a profound change in student's behavior and attitude toward the improvement of their own personal health. The usage of various suitable learning mediums in teaching and learning oral health enhances cognitive development of the students with learning difficulties. Aims and Objective: The aim of the present study was to assess the effectiveness of snake and ladder game on the level of knowledge regarding oral health knowledge, attitude, and behavior among school students with learning difficulties. Materials and Methods: The present cross-sectional study was conducted among 300 children, aged 7-9 years who were recruited in this study from the schools. A quasi-experimental pre- and post-test with control group design was adopted. Results: The total score was calculated based on the response to each statement. All variables of the questionnaires are analyzed by age. Differences were assessed by the " $t$ " test. SPSS, version 21 , were used to process and analyze the data. The significance level ( $P$-value) is set at 0.001 . Conclusion: The present study implies that the play way method of teaching children with snake and ladder board is an effective intervention to increase the knowledge of oral health among children.
\end{abstract}

Key words: Snakes and ladders game, learning difficulties, cognitive development, school children

\section{INTRODUCTION}

Educators are looking for ways and means to make learning more fun and interactive. One way to achieve this is using games. Using games in education are an ever-increasing phenomenon. Scholars agree that using games in the classroom provides numerous benefits. Learning a language can be a scary and mind-boggling experience to students. ${ }^{[1]}$

A teaching method is a way in which a teacher organizes and manages the teaching-learning

\begin{tabular}{|l|l|}
\hline Quick Response Code & Article Info: \\
\hline doi: 10.5866/2018.10.10160 \\
\hline $\begin{array}{l}\text { Received: } 26-09-2018 \\
\text { Revised: } 29-10-2018 \\
\text { Accepted: } 21-11-2018 \\
\text { Available Online: } 05-01-2019 \text { (www. } \\
\text { nacd.in)@ NAD, } 2019 \text { - All rights } \\
\text { reserved }\end{array}$ \\
\hline
\end{tabular}

situation, which presents clear explanations and vivid descriptions, assigns, and checks if learning interacts effectively with learners through questions and probes, answers, and reactions, and praise criticism (Schulman, 1999). According to Carl (1995), a teaching method is a way of facilitating interaction between the teacher and learners to realize set goals. ${ }^{[2]}$

Gaming is an educational strategy that facilitates and reinforce child learning in a stimulating and dynamic format. Good health habits (dental health) begin at home and child daycare or preschool environment should support them. ${ }^{[3]}$

Using snake and ladder game, we can educate a child and even change an entire generation. Moreover, educate the child through snake and ladder by means of win or lose approach, but anyway we will definitely walk away with valuable information about how to react swiftly safely. ${ }^{[4]}$ 
Dentists play an integral role in preventing oral health problems. Dentists are the active members of the preventive educational program and serve as counselor to the families regarding the importance of regular dental care, oral hygiene, and dietary management. Dentists should encourage good oral hygiene and teach correct brushing technique to both children and their parents. Restriction of carcinogenic foods is important to prevent dental caries, but should not be communicated in such a way, that the child interprets the withholding of sweets as a punishment. ${ }^{[5]}$

Oral hygiene though, a very cheap form of the preventive health measure, surprisingly, it has remained most neglected in the rural communities. Before providing oral health education, it is necessary to find out the state of knowledge and oral habit of children. ${ }^{[6]}$

Therefore, the investigator felt that there is an urgent need to investigate the oral health status of children in the rural communities and identify strategies to improve on them. The investigator strongly believes that oral health practices and care during childhood will determine the lifetime oral health status. The present study had attempted to educate oral hygiene to children using snake and ladder game.

\section{MATERIALS AND METHODS}

\section{Research Objectives}

The objectives are as follows:

a) To assess the effectiveness of snake and ladder game, on the level of knowledge regarding oral hygiene in school children at selected schools both in experimental and control group, Tirupati.

b) To identify the use of a snake and ladder game to improve the cognitive development of students with learning difficulties.

\section{Research Approach}

The quantitative evaluative approach was adopted for this study. The design of the research used was a game, dental awareness, and questionnaire for collecting data. Cognitive development is different for children because they are in a different class.

\section{Research Design}

The research design chosen for this study was quasi-experimental pre- and post-test with control group design [Table 1; Flowchart 1].

\begin{tabular}{|c|c|c|}
\hline Experimental group & $\begin{array}{l}\text { Game (Pre-test) and } \\
\text { Educate ( }\left(1^{\text {st }} \text { day) }\right.\end{array}$ & $\begin{array}{l}\text { Post-test } \\
\left(16^{\text {th }} \text { day }\right) .\end{array}$ \\
\hline Control group & $\begin{array}{l}\text { Screening } \\
\left(1^{\text {st }} \text { day }\right)\end{array}$ & $\begin{array}{l}\text { Post-test } \\
\left(16^{\text {th }} \text { day }\right) .\end{array}$ \\
\hline
\end{tabular}

\section{Study Area}

The present descriptive cross-sectional study was conducted during February-March 2018 at Government schools in and around Tirupati, Andhra Pradesh, India.

\section{Inclusion Criteria}

The following criteria were included in the study:

a) Children of age group 7-9 years.

b) Who can understand and speak local language (Telugu).

c) Willing to participate in the study.

\section{Exclusion Criteria}

a) Children not present on the day of the study.

b) Children of age above 9 years.

c) Children who were in the pilot study.

d) Children who were not willing to participate in the study.

e) Special children were excluded.

\section{Study Population and Sampling Technique \\ Pilot study}

Before carrying out of the study, a power analysis was performed to identify the sample size required to accurately detect significant effects. A pilot study was done with three teachers, each from standard second up to standard fourth to ensure that the data collection instrument was suitable for the research and hence to ensure validity and reliability of results.

According to Zikmund, a pilot study is defined as collected data for a small-scale exploratory research project that uses sampling but does not apply rigorous standards. ${ }^{[7]}$ The above was confirmed by Cooper and Schindler (1998) who posited that the purpose of a pilot study is to detect the weaknesses in the design and instrumentation of a research instrument and also to provide proxy data for sections of a probability sample.

To ensure the suitability of the research instruments, the present research conducted a pilot study. Pilot study was conducted at different school from March 12, 2018 to March 28, 2018 with a sample 


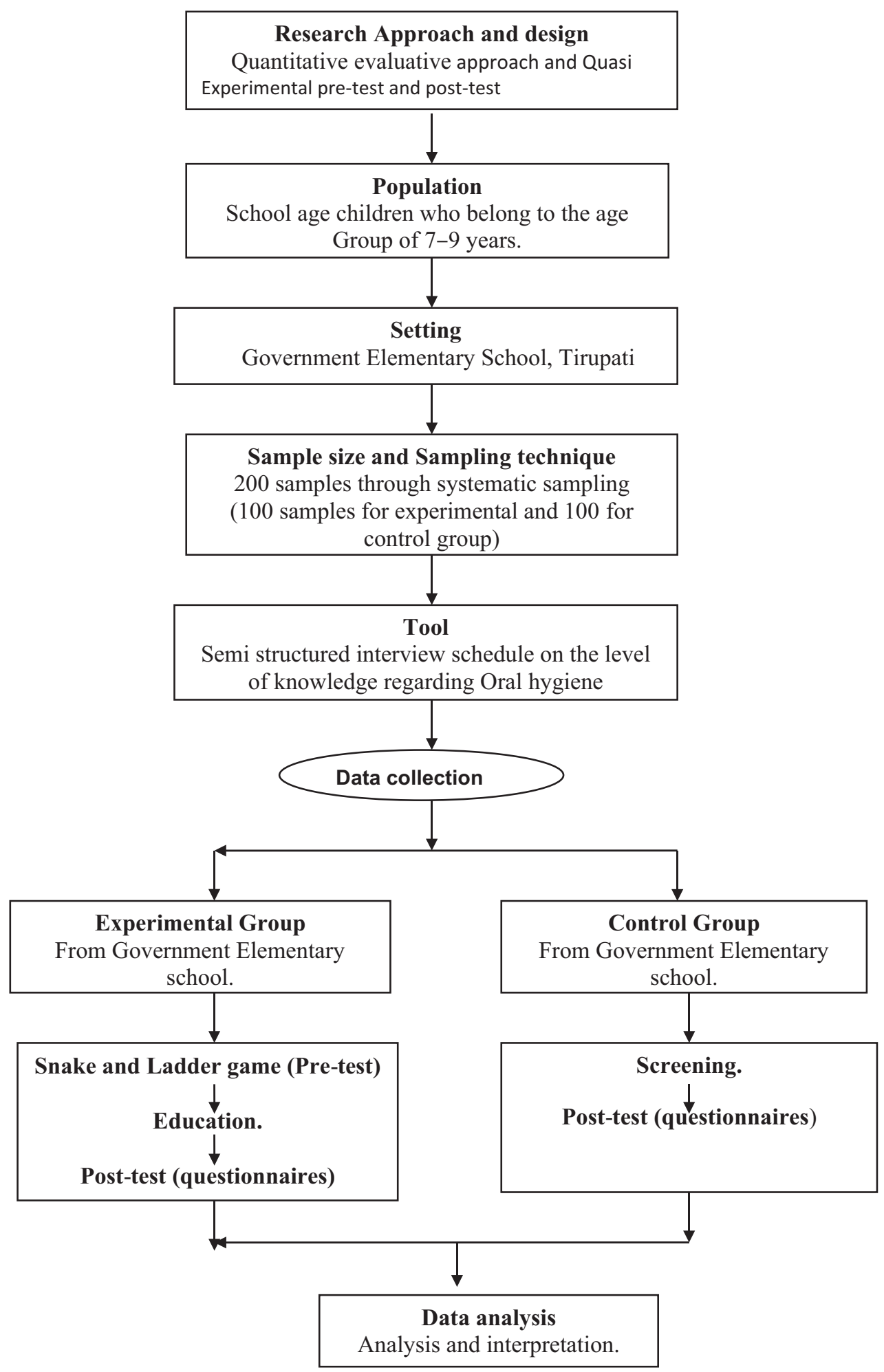

Flow Chart 1: Schematic representation of research methodology

size of 10. Snake and ladder game was taught and made them to play for 1 day and the post-test was conducted after 15 days. The finding of the pilot study revealed the feasibility of proceeding to the 
main study. Thus for a virgin quality participatory assessment, the game board played by the children in this study was video recorded and documented.

\section{Method of Data Collection}

\section{Ethical considerations}

Official permission to examine the school-children was obtained from the school authorities of schools and written informed consent was obtained from parents of children who are participating in the study. The school principal and parents were explained about the purpose and procedures of this study.

\section{Description of the Tool}

The tools were prepared by the investigator after extensive study of the related literature and with the guidance of the experts. The tool consists of two sections:

- Section-I: Demographic variables [Table 2] - the demographic profile consists of nine variables such as age, sex, class of studying, education, occupation of parents, type of family, birth order of child, and previous information regarding oral hygiene and source of information.

- Section-II: Pre-test and post-test teaching, subsequently semi-structured questionnaires to assess the level of knowledge regarding oral hygiene of school children.

The research design chosen for the present study was quasi-experimental pre- and post-test with control group design.

\section{Selection of Children for the Study}

Population is defined as any entire group of items like objects, people, materials etc; that possess at least one basic defined characteristic in common ,for example all patients in the hospital, all school children. ${ }^{[8-10]}$

The technique adopted for this study was a systematic random sampling. All the children were of Asian Indian origin. The sample size was 150 (75 boys and 75 girls) children in the age group of 7-9 years.

Care was taken, to include children of the same socioeconomic status. The age, socioeconomic status, and the ethnicity of the child were obtained from the school records.

The children were divided into two subgroups based on their chronological age.

a) Group I: 7.1-8 years.

b) Group II: 8.1-9 years.
Informal screening by the investigator was carried out to ensure that all the children had normal or corrected visual abilities.

\section{Sampling}

On the pre-decided days, the investigator visited six schools. With the help of school authorities, classrooms were arranged.

Data collection was done from May 7, 2018 to May 31, 2018. The investigator personally visited the selected school and introduced himself. The researcher collects the details of the school children through semi-structured interview schedule. Pretest was conducted for both experimental and control group for 2 days. The investigator explained the rules for snake and ladder game and makes them play under the supervision of the investigator.

The intervention was started from the $3^{\text {rd }}$ day and includes health education through flashcard.

The present study employed a survey research design which is defined as a systematic research design for collecting data from a representative sample of individuals using instruments composed of either closed-ended or open-ended questions, observations, and interviews. ${ }^{[8,10]}$

\section{Knowledge Test Questionnaire}

Knowledge questionnaire comprised 25 questions to test the knowledge on oral hygiene among children [Table 3 and 4]. Post-test was conducted on the $16^{\text {th }}$ day of intervention for each child for experimental group and control group on the last day of data collection (May 31, 2018). Data related to oral health behavior were collected using the English version of the Hiroshima UniversityDental Behavioral Inventory questionnaire, which was originally developed by Kawamura et al. ${ }^{[11]}$ Each question had three options for the respective questions in which, one will be the correct answer. All information, which was provided by the participant, was kept confidential.

The tool consisted of 26 questions under three headings, namely oral health, brushing, and diet.

\section{Scoring Key}

a) Total score is 25 .

b) Each correct response carries one mark.

Table 2: level of knowledge marks percentage

\begin{tabular}{lcc} 
Level & Marks & Percentage \\
\hline Inadequate & $0-12$ & $48-50$ \\
Adequate & $13-25$ & $50-100$ \\
\hline
\end{tabular}


Table 3: Parents according to their demographic variables in experimental and control group

Individual scenario

\begin{tabular}{|c|c|c|c|c|c|c|c|}
\hline \multirow[t]{2}{*}{ Variables } & \multirow[t]{2}{*}{ Respondents } & \multicolumn{3}{|c|}{ Experimental group $(n=150)$} & \multicolumn{3}{|c|}{ Control group $(n=150)$} \\
\hline & & Freq & ncy (n) & $\begin{array}{l}\text { Response } \\
\text { rate }(\%)\end{array}$ & Freq & ncy (n) & $\begin{array}{c}\text { Response } \\
\text { rate }(\%)\end{array}$ \\
\hline \multirow[t]{2}{*}{ Age of the child } & $7.1-8$ years & \multicolumn{2}{|c|}{52} & 34 & \multicolumn{2}{|c|}{47} & 31 \\
\hline & 8.1-9 years & \multicolumn{2}{|c|}{98} & 65 & \multicolumn{2}{|c|}{103} & 68 \\
\hline \multirow[t]{2}{*}{ Sex of the child } & Male & \multicolumn{2}{|c|}{75} & 50 & \multicolumn{2}{|c|}{75} & 50 \\
\hline & Female & \multicolumn{2}{|c|}{75} & 50 & \multicolumn{2}{|c|}{75} & 50 \\
\hline \multirow[t]{3}{*}{ Class of studying (standard) } & II & \multicolumn{2}{|c|}{45} & 30 & \multicolumn{2}{|c|}{40} & 26 \\
\hline & III & \multicolumn{2}{|c|}{57} & 38 & \multicolumn{2}{|c|}{59} & 39 \\
\hline & IV & \multicolumn{2}{|c|}{48} & 32 & \multicolumn{2}{|c|}{51} & 34 \\
\hline \multirow[t]{3}{*}{ Birth order of the child } & One & \multicolumn{2}{|c|}{64} & 42 & \multicolumn{2}{|c|}{71} & 47 \\
\hline & Two & \multicolumn{2}{|c|}{60} & 40 & \multicolumn{2}{|c|}{54} & 36 \\
\hline & Three and above & \multicolumn{2}{|c|}{26} & 17 & \multicolumn{2}{|c|}{25} & 16 \\
\hline \multirow{2}{*}{$\begin{array}{l}\text { Previous information } \\
\text { regarding oral hygiene }\end{array}$} & Yes & \multicolumn{2}{|c|}{75} & 50 & \multicolumn{2}{|c|}{75} & 50 \\
\hline & No & \multicolumn{2}{|c|}{75} & 50 & & & 50 \\
\hline If yes, source of information & Family members & & 1 & 20 & & & 23 \\
\hline & Electronic media & & 8 & 45 & & & 44 \\
\hline & $\begin{array}{l}\text { Any Other (Health } \\
\text { professionals, Teachers) }\end{array}$ & & 1 & 34 & & & 32 \\
\hline & & Male & Female & $\begin{array}{c}\text { Response } \\
\text { rate }(\%)\end{array}$ & Male & Female & $\begin{array}{c}\text { Response } \\
\text { rate }(\%)\end{array}$ \\
\hline Education level of parents & Graduate & 0 & 0 & 0 & 0 & 0 & 0 \\
\hline & School & 41 & 44 & 56 & 37 & 44 & 54 \\
\hline & Illiterate & 34 & 31 & 43 & 38 & 31 & 46 \\
\hline Occupation of the parents & Skilled worker & 7 & 6 & 8 & 0 & 14 & 9 \\
\hline & Semi-skilled worker & 41 & 36 & 65 & 38 & 33 & 47 \\
\hline & Unskilled worker & 27 & 33 & 40 & 37 & 28 & 43 \\
\hline Type of family & Joint & 63 & & 42 & 61 & & 40 \\
\hline & Nuclear & 87 & & 58 & 89 & & 59 \\
\hline
\end{tabular}

c) Each wrong response carries 0 marks.

Table 3 depicts interpretations of the level of knowledge regarding oral hygiene.

\section{Booklet for Parents}

A booklet on "child's oral health in your hands" was prepared with health and nutrition messages for the parents and children. The booklet especially focuses on oral health and good oral hygiene instructions. Booklets were distributed to the parents of all the selected children.

\section{Statistical Analysis}

The data were collected, arranged, tabulated. Independent " $t$ " test was used to access the effectiveness of snake and ladder game.

\section{DATA ANALYSIS AND INTERPRETATION (RESULTS) [TABLE 5]}

Polit et al. defined that analysis is the process of organizing and synthesizing in such a way that question can be answered and hypothesis tested. ${ }^{[10}$

The analysis and interpretation of data collected evaluated the effectiveness of snake and ladder game on the level of knowledge of children from schools regarding oral hygiene in and around Tirupati.

Distribution of children in experimental and control group according to their age showed that the majority of the children in experimental 98 (65\%) and control group $103(68 \%)$ belong to $8.1-9$ years of age. 
Table 4: Distributions of questionnaire items of the HU-DBI by agree responses (Oral health knowledge of school students) Individual scenario

\begin{tabular}{|c|c|c|c|c|}
\hline \multirow[t]{2}{*}{ Variables } & \multicolumn{2}{|c|}{$\begin{array}{l}\text { Experimental } \\
\text { group }(n=150)\end{array}$} & \multicolumn{2}{|c|}{$\begin{array}{l}\text { Experimental } \\
\text { group }(n=150)\end{array}$} \\
\hline & $\begin{array}{c}\text { Frequency } \\
\text { (n) }\end{array}$ & $\begin{array}{c}\text { Response } \\
\text { rate }(\%)\end{array}$ & $\begin{array}{l}\text { Frequency } \\
\text { (n) }\end{array}$ & $\begin{array}{c}\text { Response } \\
\text { rate }(\%)\end{array}$ \\
\hline \multicolumn{5}{|l|}{ Related to oral health } \\
\hline What is Oral hygiene? & 120 & 80 & 88 & 58.6 \\
\hline Why Oral hygiene important? & 99 & 66 & 91 & 60.6 \\
\hline What is Dental Caries? & 106 & 70.6 & 59 & 39.3 \\
\hline What causes tooth decay? & 93 & 62 & 74 & 49.3 \\
\hline How often do we need to visit a Dentist? & 102 & 68 & 42 & 28 \\
\hline \multicolumn{5}{|l|}{ Related to brushing } \\
\hline How frequently tooth brush must be changed? & 135 & 90 & 113 & 75.3 \\
\hline How many minutes' teeth are to be brushed? & 113 & 75.3 & 70 & 53.3 \\
\hline How much of paste is to be used for brushing? & 122 & 81.3 & 70 & 46.6 \\
\hline How often teeth is to be brushed? & 140 & 93.3 & 110 & 73.3 \\
\hline How to take care of brush after brushing the teeth? & 139 & 92.6 & 103 & 68.6 \\
\hline What are the methods used to maintain Oral hygiene & 124 & 82.6 & 92 & 61.3 \\
\hline What is the purpose of brushing teeth? & 132 & 88 & 75 & 50 \\
\hline What is to be done after getting up in the morning? & 149 & 99.3 & 119 & 79.3 \\
\hline What material is used to clean the teeth? & 144 & 96 & 108 & 72 \\
\hline When the mouths need to be rinsed? & 129 & 86 & 93 & 62 \\
\hline Which substance is the best dentifrice? & 144 & 96 & 112 & 74.6 \\
\hline Which technique cleanses the teeth better? & 121 & 80.6 & 75 & 50 \\
\hline Which toothpaste to be used for brushing? & 128 & 85.3 & 98 & 65.33 \\
\hline \multicolumn{5}{|l|}{ Related to diet } \\
\hline How does calcium help the teeth? & 89 & 59.3 & 50 & 33.3 \\
\hline How to remove the food particle that is present in between teeth? & 131 & 87.3 & 87 & 58 \\
\hline What diet is needed to have strong teeth? & 118 & 78.6 & 84 & 56 \\
\hline What is to be done after eating sticky chocolates? & 119 & 79.3 & 93 & 62 \\
\hline Which is good for Oral health? & 88 & 58.6 & 41 & 27.3 \\
\hline Which is more preferential liquid drink before going to bed? & 120 & 80 & 83 & 55.3 \\
\hline Which one of the following is a cause for tooth decay? & 115 & 76.6 & 100 & 66.6 \\
\hline
\end{tabular}

Distribution of children in the experimental and control group according to the gender were similar.

Distribution of children in the experimental and control group according to the class of studying shows that majority of children $57(38 \%)$ in experimental and 59(39\%) in control group were in $3^{\text {rd }}$ standard/class.

Distribution of children according to the birth order of children shows that higher percentage of 64 $(42 \%)$ in the experimental group was $1^{\text {st }}$ born child and $71(47 \%)$ children in the control group.
Distribution of children according to the previous information acquired regarding oral hygiene, depicts that almost all of the children $75(50 \%)$ in the experimental group and all children 75 (50\%) in control group got information regarding oral hygiene from electronic media [Table 1].

Distribution of children according to the educational status of parents depicts that majority in experimental group $85(56 \%)$ and $81(54 \%)$ in the control group had studied up to the school level. 
5: Knowledge level scores before and after interventions in experimental and control group

\begin{tabular}{|c|c|c|c|c|c|c|c|c|}
\hline \multirow[t]{3}{*}{ Level } & \multicolumn{4}{|c|}{ Experimental group $(n=150)$} & \multicolumn{4}{|c|}{ Control group $(n=150)$} \\
\hline & \multicolumn{2}{|c|}{ Pre test } & \multicolumn{2}{|c|}{ Post test } & \multicolumn{2}{|l|}{ Pre test } & \multicolumn{2}{|c|}{ Post test } \\
\hline & $\begin{array}{c}\text { Frequency } \\
\text { (n) }\end{array}$ & $\begin{array}{c}\text { Response } \\
\text { rate }(\%)\end{array}$ & $\begin{array}{c}\text { Frequency } \\
\text { (n) }\end{array}$ & $\begin{array}{c}\text { Response } \\
\text { rate }(\%)\end{array}$ & $\begin{array}{l}\text { Frequency } \\
\text { (n) }\end{array}$ & $\begin{array}{l}\text { Response } \\
\text { rate }(\%)\end{array}$ & $\begin{array}{l}\text { Frequency } \\
\text { (n) }\end{array}$ & $\begin{array}{c}\text { Response } \\
\text { rate }(\%)\end{array}$ \\
\hline \multicolumn{9}{|c|}{ Related to oral health } \\
\hline Adequate & . & & 104 & 69 & No Pre-test & & & \\
\hline Inadequate & 68 & 45 & & & No Pre-test & & 71 & 47 \\
\hline \multicolumn{9}{|c|}{ Related to brushing } \\
\hline Adequate & 98 & 65 & 132 & 88 & No Pre-test & & 95 & 63 \\
\hline Inadequate & & & & & No Pre-test & & & \\
\hline \multicolumn{9}{|l|}{ Related to diet } \\
\hline Adequate & 84 & 56 & 111 & 74 & No Pre-test & & & \\
\hline Inadequate & & & & & No Pre-test & & 74 & 49 \\
\hline
\end{tabular}

6: Effectiveness of snake and ladder game on post test level of knowledge score of children regarding oral hygiene in experimental and control group

\begin{tabular}{|c|c|c|c|c|c|c|c|c|}
\hline \multirow{4}{*}{ Variable } & \multirow{4}{*}{$\begin{array}{c}\text { Max } \\
\text { score }\end{array}$} & \multicolumn{4}{|c|}{ Groups } & \multirow{4}{*}{$\begin{array}{c}\text { Mean } \\
\text { difference }\end{array}$} & \multirow{4}{*}{$\begin{array}{c}\text { Post } \\
\text { test } \\
\text { 't' value }\end{array}$} & \multirow{4}{*}{$\begin{array}{l}\text { Inferential } \\
\text { statistics }\end{array}$} \\
\hline & & \multirow{2}{*}{\multicolumn{2}{|c|}{$\begin{array}{c}\text { Experimental group } \\
\text { Post test } \\
\end{array}$}} & \multirow{2}{*}{\multicolumn{2}{|c|}{\begin{tabular}{|c|} 
Control group \\
Post test \\
\end{tabular}}} & & & \\
\hline & & & & & & & & \\
\hline & & Score & Mean \pm S.D & Score & Mean \pm S.D & & & \\
\hline Related to oral health & 5 & 520 & $104 \pm 1.65$ & 354 & $70.8 \pm 3.36$ & 33.20 & 77.6 & $\begin{array}{c}P<0.001 \\
\quad \text { SS }\end{array}$ \\
\hline Related to brushing & 13 & 1720 & $132.30 \pm 3.03$ & 1238 & $95.23 \pm 4.99$ & 37.07 & 86.64 & $\begin{array}{l}P<0.001 \\
\quad \mathrm{SS}\end{array}$ \\
\hline Related to diet & 7 & 780 & $111.42 \pm 3.29$ & 520 & $74.28 \pm 4.20$ & 37.14 & 86.80 & $\begin{array}{l}P<0.001 \\
\quad \mathrm{SS}\end{array}$ \\
\hline Over all & 26 & 1006 & $347.42 \pm 7.97$ & 523.51 & $240.31 \pm 12.52$ & 24 & 77.83 & $\begin{array}{c}P<0.001 \\
\text { SS }\end{array}$ \\
\hline
\end{tabular}

Significant at $P<0.001$ level. NS: Not significant: SS: Significant; HS: Highly significant

Distribution of children according to the occupation of the parents showed that the majority of parents $77(51 \%)$ in experimental group and 71 $(47 \%)$ in control group were semi-skilled worker.

Distribution of children according to the type of family reveals that the majority of children belong to a nuclear family in both experimental $87(58 \%)$ and control group 89 (59\%).

It seems that the knowledge of the children regarding oral hygiene had improved in the experimental group after playing snake and ladder game [Table 6].

\section{DISCUSSION}

Piaget stated that cognitive development studies on how mental skills are developed and changed based on physiological maturity and experience in which a student had gone through since childhood. Meanwhile, cognitive psychologists study on the differences and similarities in the processes that occur in mind for different ages. ${ }^{[12]}$

According to Suppiahel et al. (2010), changes in cognition are associated with quality changes in thinking, for instance, on how one's knowledge and ability have been upgraded. Cognition psychologists believe that any changes that occur in students are due to the interaction of students with their growing environment and also learning environment that they had gone through in school. Besides that, it is related to the background of family, friends, and neighborhood as well. All life experiences will deeply influence the changes in students' cognition. Suppiah et al. (2010) concluded that snake and ladder game is able to improvise the 
cognitive development of students with learning difficulties. ${ }^{[9]}$

According to Arbiah et al., the theory of cognition or information processing theories of memory has been classified into three main sections, namely: ${ }^{[13]}$

a) Long-term memory

b) Short-term memory

c) Sensory memory

Marilyn, (2011), stated that students with learning difficulties are having problems in their long-term memory and short-term memory. They are unable to remember what they had learned either in long-term memory or short-term memory and also to ensure those concepts that they had learned to be processed and saved in their brain, too. Based on the principles of cognitive theory, learning would take into account, the ability of a student to receive the information provided. This means that the quantity of information to be presented at a time must be controlled so that it does not exceed the capacity of short-term memory for a student with learning difficulties. ${ }^{[14]}$

Therefore, reading about cognitive learning theory provides a suitable material for researchers to conduct research fulfilling the objective of the research. The use of snake and ladder game in class is to ensure that the students with learning disabilities are able to understand the concept of mathematics. ${ }^{[14]}$

According to Schriff (2009), snake and ladder game was created in the $2^{\text {nd }}$ century $\mathrm{BC}$ by the name of "Paramapada Sopanam" (Ladder to Salvation). The game had been developed by the Hindus to teach their children as a lesson of morality whereby the snakes are bad omens and the staircase represents good values. Then, the game has become part of the traditional game in Indonesia although there is no detailed information about its emergence in Indonesia. This game can also be used as a tool to educate, entertain, and to build up interactive communication among the players. ${ }^{[15]}$

According to Ary, the report states that there is no standard game board for snake and ladder game. Everyone can create their own game boards with the total number of compartments, different number of snakes and ladders, respectively, that suit the players. ${ }^{[16]}$

Snakes and ladders in health education were designed by Kneebone and Guthrie for the Disabilities Study Unit in Co-operation with the Child-to-Child programme. ${ }^{[17]}$

\section{Snake and Ladder Game [Figure 1]}

Snakes and ladders are a popular game for children in many countries of the world. It is easily made from basic materials and can be adapted to suit many learning situations.

Snakes and ladders game board entitled "tips for healthy life" was especially designed as an outdoor game for children. The game board was structured using Photoshop and Corel Draw X3 software. It was magnified into ten by ten feet high resolution on a premier quality flex sheet. This board comprised hundred squares and each square was one by one feet which was spacious enough for a child to stand during the play. A pair of big dice was prepared to meet the large size of the game board. In this specially designed game, ladders represented positive health concepts and snakes depicted negative health concepts. The game board is given in Figure 1. This game board comprises eight positive health concepts as ladders and eight negative health concepts as snakes. The health concepts were centered toward good oral hygiene.

Of great importance in any game is the rule. The present study was a modification of the board game, snakes and ladders. In educational terms, the rules equate to "devising and planning investigations" which is one of our process skill objectives.

In addition, snakes and ladders can assist in developing basic arithmetic such as counting, addition and subtraction, communication, as well as the concept for which a game has been developed such as nutrition and health education.

According to Rahman Faizal (2010), there are some rules in the snake and ladder game:

\section{Rules}

a) Players of differing abilities are given questions at different levels of difficulty thus making the game challenging to all.

b) The game is played between two players.

c) A game board for snake and ladder game is with squares measuring $10 \times 10$. Squares on the board are counted starting with the number 1 , which is from the bottom left corner up to number 10 in the lower right corner, from right to left starting number 11 on the second line until number 20 and so on until the number 100 in the upper left corner.

d) The parcels have pictures with a message and deed. Order or good deeds will usually through a ladder to reach the higher box while bad deeds 
will recoil into the lower compartment through the snake.

e) Each player starts with their marker on square 1, marked START, which is at the bottom left-hand corner of the board. Different colored pieces of plastic make good markers.

f) To decide who goes first, each player must shake and throw the dice; the first player to get a six starts the game. He/she then throw again and moves their marker forward the number of squares indicated on the dice (i.e., 1, 2, 3, 4, 5, or 6 squares).

g) On the board, there are lines linking various squares. There are certain amounts of snakes and ladders located on particular parcels on the board. If you are at the bottom of one of these lines, the line represents a ladder; if at the top the same line represents a snake.

h) In the course of the game, any player landing on a snake/ladder is asked a question by his opponent. If the correct answer is given then the ladder is ascended or descending the snake is avoided (the opposite occurs if the answer is incorrect, or no answer is given).

i) The time required is variable. If the game is not completed within 15-20 min, the winner is the furthest one up the board.

j) The player who made it to the box of 100 will be the winner of this game.

Holtman concluded that people with lower education levels experience disadvantage with respect to access to dental services with significant variation in all access indicators by education level. ${ }^{[6]}$

The present study findings were supported by Prasanthi, (2004) who conducted an experimental study on the effectiveness of snake and ladder on knowledge of oral hygiene among 100 school children in Bengaluru. The findings of the study concluded that post-test mean score was higher than the pre-test mean score and the estimated' value was 19.16 scores at $P<0.05$ level. It proved that snake and ladder game was effective in improving the knowledge of children.

The control group findings of the present study supported by the Nakara, (2009), conducted a study on the promotion of oral hygiene through child to child program in Pune. It was concluded that there was an association between the level of knowledge and demographic variables such as age, type of family, and education level of mother.
The present study was supported by the World Population Survey (2010) of ranking of states and union territories by literacy rate shows that majority $(82.33 \%)$ of male are literates and $64.55 \%$ of females are literates in Tamil Nadu (World Population and Housing Census Programme).

The present study finding was supported by Devi, (2006), wherein her study she assessed the effectiveness of STP regarding dental hygiene among school children in Trichy. The result found that higher percentage of the children 12 $(40 \%)$ in the experimental group and $10(33 \%)$ in control group had moderately adequate knowledge during pre-test and $1(3 \%)$ in control group and $18(60 \%)$ in the experimental group had adequate knowledge. Further none of them in the experimental group and $19(63 \%)$ in the control group had inadequate knowledge during post-test.

\section{Limitation}

1. Only 150 samples.

2. Only 4 weeks.

3. School children who are 7-9 years old.

4. The school children of selected rural schools, Tirupati.

\section{Recommendations}

1. A similar study can be done on a large sample to generalize the findings.

2. A comparative study can be done between rural and urban children on the level of knowledge, attitude, and practice regarding oral hygiene.

3. A similar study can be done to determine the effectiveness of snake and ladder game among school children for various topics.

4. A comparative study can be performed to evaluate the effectiveness of snake and ladder game with health education and game without health education on oral hygiene.

5. A study can be done to assess the effectiveness of structured teaching program on oral hygiene among school children.

6. A descriptive study can be done to find out the incidence of dental carries among school-age children.

7. A similar study can be done to assess the effectiveness of teaching oral hygiene to school children through the child to child program. 


\section{Significance of the Study}

1. Based on the finding of the study, it is also expected that the researcher knows how the schoolchildren learn what they enjoy, on oral hygiene. The researcher should also know the learners' characteristics of oral hygiene.

2. Through the research that had been conducted, it is highly recommended that snake and ladder game is to be exposed among students, even though most of the teachers may not agree as this method will take a long teaching and learning session which is the major limiting factors of this activity.

3. The relevance of this study is to use a variety of media-learning of oral hygiene for students to overcome their learning difficulties.

4. As a result of the research conducted, hopefully, the use of snake and ladder game will enhance the cognitive development and to overcome the learning difficulties in mastering the concepts and skills of oral hygiene.

\section{Summary}

A quasi-experimental study was conducted to assess the effectiveness of snake and ladder game on the level of knowledge on oral hygiene among 150 school children selected by systematic random sampling technique. Semi-structured interview schedule was used to assess the knowledge of school children on oral hygiene. The data collected were analyzed using descriptive and inferential statistics.

\section{CONCLUSION}

The present experimental study was done to assess the effectiveness of snake and ladder game on the level of knowledge regarding oral hygiene among school children in selected schools, Tirupati. The findings of the study showed that the snake and ladder game was more effective in improving the knowledge of the children regarding oral hygiene. There was no association between the post-test knowledge score.

Oral hygiene is essential for every human being and plays way was an effective and simple way to teach children regarding oral hygiene. As a healthcare professional, we are in the position to educate children and thereby, to adopt good and healthy practice. The investigator received a clear idea regarding the different steps to be taken in different fields to improve the same.

\section{Ethical Disclosures}

- Protection of human and animal subjects: The authors declare that no experiments were performed on humans or animals for this study.

- Confidentiality of data: The authors declare that no patient data appear in this article.

- Right to privacy and informed consent: The authors have obtained the written informed consent of the patients or subjects mentioned in the article. The corresponding author is in possession of this document.

\section{CONFLICTS OF INTEREST AND SOURCE OF FUNDING}

The author declares that there is no special financial support for this research work from the funding agency and there is no conflict of interest among all authors.

\section{ACKNOWLEDGMENT}

All the authors express sincere gratitude to all respondents whose honest attention help and support and the participants of the study lead the research project to the worthful outcome.

\section{REFERENCES}

1. Musa A. Noun-it-right snake and ladder board game: Learning about nouns an enhancement tool in the teaching of grammar. JCPLT 2016;4:31-9.

2. Norman R. The use of motivational teaching methods in primary schools mathematics in Zimbabwe: A case of the first decade after independence. Int J Voc Tech Educ 2015; $1: 15-29$

3. Aljafari A, Rice C, Gallagher JE, Hosey MT. An oral health education video game for high caries risk children: Study protocol for a randomized controlled trial. Trials 2015; 16:237-40.

4. Warburton J, Madge C. The snakes and ladders of research: Using a board game to teach the pitfalls of undergraduate research design. J Geogr Higher Educ 1994;18:237-44.

5. Gibson B, Gregory J, Robinson PG. The Perceived relevance of Oral health. Br Dent J 2007;7:406-7.

6. Holtman JR. Oral health and access to dental care comparisons by level of education. Aust Dent J 2005;51:342-4.

7. Zikmund WG. Business Research Methods. $7^{\text {th }}$ ed. Fort Worth: Dryden Press; 2003

8. Zera DA, Lucian DG. Self-organization and learning disabilities: A theoretical perspective for the interpretation and understanding of dysfunction. J Learn Disabil 2001; 24:107-18

9. Nachiappan S, Rahman NA, Harikrishnan C, Faly FM Snake and ladder games in cognition development on students with learning difficulties. Rev Arts Hum 2014; 3:217-29. 
10. Polit DF, Beck CT, Hungler BP. Essentials of Nursing Research: Methods, Appraisal, and Utilization. $5^{\text {th }}$ ed. Philadelphia, PA: Lippincott; 2001.

11. Kawamura M, Sasaki T, Imai-Tanaka T, Yamasaki Y, Iwamoto Y. Service mix in a general dental practice in Japan A survey in a sub-urban area. Aust Dent J 1998;43:410-6.

12. Piaget J. The development of thought: Equilibration of cognitive structures. Oxford, England: Blackwell; 1978.

13. Maddahiri AB, Abdullah MK, Mosin MB, Ahmid MH, Asul HB. LINUS-literacy teaching practices. Malaysia J Soc Sci Hum 2001;3:32-9.
14. Marilyn F. Special education: Contemporary perspectives for school professionals New Jersey: Pearson Education; 2011.

15. Schriff R, Bauminger N, Toledo I. Analogical problem solving in children with verbal and nonverbal learning disabilities. J Learn Disabil 2009;42:13-5

16. Ary D. Introduction to Research in Education. $5^{\text {th }}$ ed. Toronto: Harcourt Bruce College Publications; 1996.

17. Kneebone P, Guthrie D. Disability management among women with physical impairments: The contribution of physical activity. Soc Sport J 2001;18:5-20. 